\title{
MITIFICAÇÃO DA POLÍTICA E SEUS DESDOBRAMENTOS NA MODERNIDADE EM BENJAMIN
}

Francisco Valdemir de Matos $^{1}$

\author{
RESUMO
}

A análise benjaminiana de progresso (Fortschritt) e suas principais consequências, tem como laboratório a República de Weimar e sua decadência. As categorias benjaminianas explicam o processo histórico de idealização e de mitificação da política, que promoveu a ascensão do Nazismo na Alemanha. Sua estruturação no mito do belo vai conduzir a cultura à barbárie da guerra. A crítica benjaminiana à modernidade visa à falsa proposta de civilização que submergiu diante dos ideais de Adolf Hitler ( $O$ Führer). A memória, segundo Benjamin, seria o principal mecanismo para uma revolução, num instante denominado de "agora", como forma de resistência à modernidade.

Palavras-chave: Benjamin. Mitificação. Política. Modernidade. Resistência.

\section{POLITICS MITIFICACION AND ITS DEVELOPMENTS IN MODERNITY IN BENJAMIN}

\begin{abstract}
Benjamin's analysis of progress (Fortschritt) and its main consequences, as lab has the Weimar Republic. The benjaminian categories explain the historical process of idealization and mystification of politics that promoted the rise of the Nazi in Germany. Its Structure of the Myth of Beauty will lead to the culture of barbarity of war. Benjamin's critique of modernity seeks the false purpose civilization that sank on the ideals of Adolf Hitler (O Führer). He memory, according to Benjamin, was the main mechanism to a revolution in a moment called "now" as a form of resistance to modernity.
\end{abstract}

Keywords: Benjamin. Mytification. Politics. Modernity. Resistance.

O pensamento de Walter Benjamin ${ }^{2}$ situa a crítica filosófica no espaço da ambiguidade vivida pela humanidade no início do século $X X$, especialmente, pela sociedade alemã, que submersa num cenário de guerras, se sujeita à Constituição de Weimar. Essa República foi concebida como "berço" de toda a tradição da cultura clássica humanista que fundamentara o idealismo alemão e a filosofia da superação

\footnotetext{
Francisco Valdemir de Matos é Mestre em Filosofia pela Universidade Estadual do Ceará - UECE.

2 Benjamin nasceu numa Alemanha, que tinha como cenário a guerra franco-prussiana (1870). Esta leva a França, humilhada, a assinar o tratado de Frankfurt, pelo qual entrega aos alemães ricos territórios e fica sob o governo da dinastia prussiana (o rei Guilherme e o chanceler Bismarck).
} 
(Aufhebung). A imagem da águia a voar nas alturas seria o símbolo desse ideal ironicamente corrompido, dando espaço, teoricamente, às condições que vivenciou a democracia social, responsável pela manipulação da massa operária com a ilusão de que a ela cabia o desenvolvimento industrial do país. Sobre essa mentalidade erguem-se os degraus para a ascenção do nazismo e o apogeu de Hitler. A grande base da fatídica apoteose seria a criação de um Mito, para a qual o maior apelo era o Belo expresso na simetria das hordas, na figura "ariana" dos soldados perfilados, no culto do corpo, enfim na estetização geral da política. Diante dessa constatação Benjamin vai propor em sua obra a reavaliação de conceitos filosóficos, com o objetivo de alcançar um entendimento sobre "como é possível" a manipulação de valores enraizados na tradição, tais como: a Verdade, o Belo e o Bom, e sua degeneração nas relações de força, levando a humanidade à destruição do Ethos histórico ${ }^{3}$ e à transformação da cultura em barbárie. O filósofo observa que a utilização da técnica industrial, a formação da mentalidade do povo estruturada em falsos valores, o atraso no processo de unificação política, a construção de mitos (da raça, do heroísmo, da guerra, da técnica, e da soberania mundial) e o rigor do governo que surge dessa unificação (Alemanha e Prússia) deixam marcas em diversos níveis e setores da sociedade, cuja formalidade nas relações interpessoais com base no preconceito social - Pangermanismo ${ }^{4}$ - definem a categoria de uma pessoa na "boa sociedade alemã" utilizando-se dos critérios de ancestralidade que dividem o povo alemão. Esse preconceito alimenta o antissemitismo.

A nação dos facistas, com seu rosto de esfinge, constitui-se num novo mistério da natureza, de caráter econômico, ao lado do antigo, que, longe de se iluminar com a luz da técnica, revela agora os seus traços

\footnotetext{
BENJAMIN, Origem do Drama Barroco Alemão. (Trad. Sérgio Paulo Rouanet). São Paulo: Brasiliense, 1984. p.111.

${ }^{4}$ Cf. Reich Wilhelm, Psicologia de massas do Facismo. São Paulo: Martins Fontes, 2001. Neste período do Chanceler Bismarck havia na Alemanha uma sociedade de castas, onde a categoria social de pais e avós definia a dos seus descendentes, ou, no caso dos diplomados universitários, a titulação apagaria a memória da ancestralidade, colocada, neste caso, em segundo plano. Já os comerciantes e industriais (Nouveaux e Riches), que tinham ascensão econômica sem ter passado pelos sangrentos rites de passage dos militares e estudantes, eram olhados com sobranceria pela "boa sociedade" dos Kaiserzeit como portadores do indelével estigma de origens humildes, sendo considerados como "alpinistas sociais"e parvenus. Só mais tarde, levando-se em conta que a Alemanha teve um desenvolvimento tardio enquanto estado-nação, é que os comerciantes e industriais viriam a constituir o estrato social mais poderoso e, concomitantemente, o mais elevado da sociedade Alemã.
} 
fisionômicos mais ameaçadores. No paralelogramo de forças constituído pela natureza e pela nação, a diagonal é a guerra ${ }^{5}$.

Benjamin observa que é no contexto do mito de superioridade da raça que se desenvolve o conceito de política da arte alimentada pela filosofia do idealismo alemão. Os comunistas tentam reagir com o conceito de politização da arte $^{6}$, mas o filósofo dá uma "espetada" no marxismo que só compreendia a evolução do mundo na esteira do iluminismo. Nesse contexto da logocracia ${ }^{7}$ alemã (reinado da inteligência de esquerda), perde-se o referencial e o mundo torna-se símbolo.

\begin{abstract}
Logocracia, ou reinado da inteligência. A expressão pode ser facilmente traduzida por "reinado dos intelectuais" (Geistige). Com efeito, o conceito de intelectual ganhou terreno no campo da inteligência de esquerda e domina seus manifestos políticos, de Heinrich Mann a Döblin. Podemos observar imediatamente que esse conceito foi cunhado sem levar em conta a posição da inteligência no processo produtivo ${ }^{8}$.
\end{abstract}

Benjamin percebe que, sob o pretexto da falta de espaço vital, o desenvolvimento alemão que tinha como testa de ferro a social-democracia foi dominado por uma aceleração na produção de instrumentos técnicos, que não encontrava "berço" na sociedade (ainda muito imatura para interações harmônicas), mantendo um distanciamento entre essa técnica e a necessidade de esclarecimento das questões morais que teriam sido extraídas dos alemães na guerra. A burguesia Alemã forçava à exclusão do direito de co-participação da massa na ordem social.

A Alemanha logo estaria diante de um novo cenário de guerra - a Primeira Guerra Mundial (1914-1918) - saindo derrotada e responsabilizada, tendo que pagar vultosos recursos impostos pelos vencedores. O nazismo impõe ao mundo um condicionamento, onde: "todo documento de cultura é também documento de barbárie"9. É o que afirma Benjamin ao pretender construir um outro conceito de história, que denuncie a história oficial, rompendo com a história dos "vencedores".

\footnotetext{
5 BENJAMIN, W. "Teorias do facismo alemão. Sobre a Coletânea Guerra e Guerreiros, editada por Ernst Junger". in: Magia e Técnica, Arte e Política: Ensaio Sobre Literatura e História da cultura. (Tradução Sérgio Paulo Rouanet). 7 ed. São Paulo: Brasiliense, 1994. p. 71.

6 BENJAMIN, "A obra de arte na era da reprodutibilidade técnica" in:_Magia e Técnica, Arte e Política: Ensaio Sobre Literatura e História da cultura. (Tradução Sérgio Paulo Rouanet). 7 ed. São Paulo: Brasiliense, 1994. p. 196

7 Cf. BENJAMIN, W. "O Autor Como Reprodutor" in: Magia e Técnica, Arte e Política: Ensaio Sobre Literatura e História da cultura. Trad. Sérgio Paulo Rouanet. 7 ed. São Paulo: Brasiliense, 1994. p. 120.

8 BENJAMIN, "O Autor Como Reprodutor". Opus. Cit. p.126.

9 BENJAMIN, "Sobre o conceito de história in: Magia e Técnica, Arte e Política: Ensaio Sobre Literatura e História da cultura. Trad. Sérgio Paulo Rouanet. 7 ed. São Paulo: Brasiliense, 1994. p.225.
} 
Os autores da época faziam apologia aos meios técnicos, dando ênfase aos incrementos da atividade industrial, sempre em torno da perspectiva de uma nova guerra.

\begin{abstract}
Os autores falam com prazer e com muita ênfase da "primeira guerra mundial". Mas a obtusidade com que formulam o conceito da próxima guerra, sem circunscrevê-lo com qualquer idéia, mostra como sua experiência absorveu pouco as realidades da guerra de 1914, da qual costumam falar, numa linguagem altamente enfática, como de uma guerra "de alcance planetário"10.
\end{abstract}

Benjamin entende a tecnologia como a interface do homem incapaz de descrever a totalidade, pois a técnica não está preparada para debelar as formas elementares da natureza. Terminada a Primeira Guerra Mundial, sob a poeira da destruição, surgiram inúmeros autores preocupados com os efeitos da Guerra e, principalmente, com a possibilidade de novas guerras. Suas teorias ${ }^{11}$ iriam de encontro ao sistema totalitário facista, que resultaria na ascensão dos nazistas ao poder. É importante destacar que esses autores partem da experiência enquanto soldados na Primeira Guerra Mundial e, no entanto, não conseguem enxergar a realidade em torno dela, ficando suas mentes presas ao entusiasmo pelo "heroísmo" que a guerra thes proporcionaria. Suas limitações se tornam claras, quando se observa que sequer notaram o desrespeito às normas do direito internacional, não distinguindo população civil e combatente ou os recordes de destruição. O insucesso desses autores para Benjamin, está na pressa com que se apropriaram da atualidade sem uma compreensão do passado ${ }^{12}$, como meio para a construção de um presente melhor. Na imagem estatal mitificada de uma "Grande Alemanha" (Dentschland überal), Adolf Hitler impõe-se como Führer ${ }^{13}$. O Fanatismo da classe média alemã leva milhões de pessoas a aprovarem sua ascensão. Até a igreja

${ }^{10}$ BENJAMIN, "Teorias do Facismo Almão". Opus. Cit. p.62.

${ }^{11} \mathrm{Cf}$. "Os livros de guerra que inundaram o mercado literário nos dez anos seguintes não continham experiências transmissíveis de boca em boca. Não, o fenômeno não é estranho. Porque nunca houve experiências mais radicalmente desmoralizadas que a experiência estratégica pela guerra de trincheiras, a experiência econômica pela inflação, a experiência do corpo pela fome, a experiência moral pelos governantes".(BENJAMIN, W. Experiência e Pobreza. In: BENJAMIN, Magia e Técnica, Arte e Política: Ensaio Sobre Literatura e História da Cultura. ( Trad. Sergio Paulo Rouanet ). 7 ed. São Paulo: Brasiliense, 1994. p.115).

${ }^{12}$ Cf." Articular historicamente o passado não significa conhecê-lo "como ele de fato foi". Significa apropriar-se de uma reminiscência, tal como ela relampeja no momento de um perigo.[...]O perigo ameaça tanto a existência da tradição como os que a recebem". BENJAMIN, "Sobre o Conceito de História". Opus cit. p.224.

${ }^{13}$ Cf. "O poder mítico em sua forma arquetípica é mera manifestação dos deuses. Não meio para seus fins, quase não manifestação de sua vontade, antes manifestação de sua existência". (BENJAMIN, W. Zur Kritik der Gewalt, in: G. S. II, Willi Bolle.São Paulo: Cultrix, 1986. p.179). 
católica apoiou a ascensão de Hitler intimidada com a ameaça da entrada da Alemanha no totalitarismo soviético. Em seguida, a Alemanha é conduzida à guerra pelos nazistas:

\begin{abstract}
A guerra "foge a qualquer economia regida pela inteligência, em sua razão existe algo de sobre-humano, desmedido, gigantesco,algo que lembra um processo vulcânico,uma erupção elementar... uma onda colossal de vida, dirigida por uma força dolorosa, coercitiva, unitária, transbordando sobre campos de batalha, que hoje já se tornaram míticos, canalizadas para tarefas que ultrapassam os limites do que hoje pode ser compreendido". ${ }^{14}$
\end{abstract}

Benjamin compreende que a guerra escapa ao inteligível, consistindo em algo de sobre-humano. Os conceitos que emergiram da última guerra (Primeira Guerra Mundial) tais como "heroísmo" ou "pátria espiritual" convulsionaram a Alemanha. Observa ainda o filósofo que o Estado alemão, através de uma confissão de culpa frente à humanidade, tentaria transformar-se num Estado vitorioso internamente e, através do ufanismo, buscaria a unificação do povo, para dar um novo passo na direção do seu idealismo. Em seguida, o país adota o facismo como meio de naturalização de uma derrota que é histórica, para esquecer a "guerra perdida". Com isso, dá-se mais importância à perda do que à própria guerra, a que se vincula toda a substância material e espiritual de um povo. Daí a importância de seu resultado, que vai penetrando na existência dos homens, tornando-os mais ricos ou mais pobres em quadros, imagens e invenções. Nesse sentido, a guerra deixa de ser conduzida e passa a ser administrada, tornando-se a guerra de materiais $^{15}$ :

Muitas vezes os oficiais da linha de frente conduziram a guerra sem qualquer estilo, ou com a incorporação, no corpo dos oficiais e dos suboficiais das massas, do sangue inferior, da mentalidade prática e burguesa, em suma, do homem comum. Os elementos eternamente aristocráticos da atividade militar foram sendo crescentemente abolidos ${ }^{16}$.

Segundo Benjamin, a percepção idealista alemã, acreditava no "progresso" (Fortschritt) da ciência como resultado da perfectibilidade do espírito humano ${ }^{17}$, e se vê quebrantada no desenvolvimento do aparato tecnicista que só conseguiu na guerra uma "glória ilusória", apagando o valor da vida. Essa glória ilusória cria uma concepção de mundo, em que a morte universal se sobrepõe à vida universal e a batalha material se apóia numa invencível desconfiança com relação à civilização

\footnotetext{
${ }^{14}$ BENJAMIN, "Teorias do Facismo Alemão". Opus. Cit. p.64.

15 Idem. p.66.

${ }^{16}$ BENJAMIN, W. "Teorias do facismo alemão". Opus. Cit. p.63.

${ }^{17}$ BENJAMIN, W. "Sobre o conceito de história". Opus. Cit. p.229.
} 
moderna e ao mundo moral,enquanto a guerra é apresentada como uma poderosa revisora que sente o "pulso" do tempo. Suas vítimas apenas passarão de uma realidade imperfeita (temporal) para uma realidade perfeita (eterna) diz ironicamente o texto. Porém, não se pode aceitar testamento que fala de guerra, feito por quem só conheceu a guerra, de quem não sabe nada da paz. Do contrário, não teriam sido capazes de celebrá-la:

\begin{abstract}
Essa cruel concepção do mundo, da morte universal, e não da vida universal, que, no idealismo alemão, alivia o horror com a idéia de que, por trás das nuvens, existe um céu estrelado - essa orientação fundamental do espírito alemão é profundamente desprovida de vontade, diz coisas que não pensa, é um rastejar, um acovardar-se, um desejo de não saber, de não viver e de náo morrer...Pois é essa a dúbia atitude alemã com relação à vida: poder jogá-la fora, quando ela não custa nada, num momento de embriaguez, num gesto que, ao mesmo tempo, assegura o sustento dos que ficaram e aureola a vítima com uma glória ilusória ${ }^{18}$.
\end{abstract}

Chama a atenção de Benjamin, a "metamorfose" sofrida pelos combatentes durante a guerra, quando compara os rostos leves, entusiásticos dos soldados em 1914, com suas fisionomias mortalmente cansadas, tensas e esquálidas em 1918, quando tais expressões externam uma responsabilidade solitária e o isolamento de suas almas, numa luta cujo caminho estreito e perigoso era o "caminho para o fundo", uma experiência negativa que aponta para o vazio. É quando o mito penetra todas as instâncias da existência, que a vida é tratada como mera vida.Tal realidade, Ernst Jünger denomina de "mobilização total da paisagem ${ }^{19}$ ", onde toda a região se transforma em "terreno do idealismo alemão". Benjamin considera que a técnica usada na guerra modelou a natureza, "dando-lhe um rosto apocalíptico"20.

Mas a última guerra tem uma característica especial. Ela não foi somente a guerra das batalhas de material, foi também a guerra perdida. Perdida, num sentido muito particular, pelos alemães. Outros povos podem afirmar que lutaram uma guerra a partir da sua substância mais íntima. Mas nunca nenhum afirmou que a perdeu a partir da sua substância mais íntima ${ }^{21}$.

Como aponta Benjamin, "a técnica realçou os traços heróicos no rosto do idealismo alemão"22, numa tentativa de fazer renascer os ideais da cultura humanista do Renascimento na República de Weimar, porém "foi um equívoco, porque os traços que ela julgava serem heróicos eram na verdade traços

\footnotetext{
${ }^{18}$ BENJAMIN, W. "Teorias do facismo alemão". Opus. Cit. p.66-67.

${ }^{19}$ BENJAMIN, W. "Teorias do facismo alemão". Opus. Cit. p.69.

${ }^{20}$ Idem. p 70.

${ }^{21}$ BENJAMIN, "Teorias do facismo alemão". Opus. Cit. p.64.

${ }^{22}$ Ibidem.
} 
hipocráticos, os traços da morte". A civilização perde seu ethos, "Acaba-se o corpo a corpo nas batalhas,o heroísmo torna-se pura abstração, pois trata-se da guerra de materiais. Por isso, profundamente impregnada por sua própria perversidade, a guerra torna-se abstração metafísica". Benjamin fala direto do interior de uma sociedade inteiramente reificada, que realiza o progresso de forma triunfalista, configurando uma perspectiva que repele qualquer tipo de utopia positiva. É esse tempo reificado que prepara a guerra de "materiais". O filósofo parte da própria mercadoria, dos objetos vazios, sem sentido, "das ruínas da história", como marca negativa para desafiar o tempo fundado pelo iluminismo, o tempo da utopia construída pela ciência e vislumbrar outra categoria de tempo fora do tempo para por um fim ao sofrimento do outro. Quanto mais os "cacos da história" se amontoam, quanto mais desvalorizada e mortificada a história possa parecer, mais se apresenta o índice da possibilidade de sua superação na imagem dialética, ensina a teologia benjaminiana. Benjamin compreende que a luta de classes deve ser, antes de tudo, "uma luta pelas coisas brutais e materiais, sem as quais não existem as refinadas e espirituais", pois a teoria e a prática da social-democracia foram determinadas por um conceito dogmático de progresso, desvinculado da realidade:

A idéia de um progresso da humanidade na história é inseparável da idéia de sua marcha no interior de um tempo vazio. A crítica da idéia do progresso tem como pressuposto a crítica da idéia dessa marcha. ${ }^{23}$

O "carater destruidor" da crítica Benjaminiana, tem por objetivo despertar a consciência crítica das classes oprimidas sobre a ascensão do nazismo e a violência do III Reich. Este "tempo de guerra e de mitos" observado por Benjamin, corresponde ao de uma particular guerra ideológica entre o professorado alemão, ligado, em grande parte às tradições hierárquicas do passado feudal e aristocrático, e a intelectualidade livre e democrático-socialista da cultura urbana de Weimar, em grande parte judia. Na ironia benjaminiana, percebe-se que o que resta desse sujeito lógico, construído pelo idealismo com base na reflexão é a própria classe combatente e oprimida.

O sujeito do conhecimento histórico é a própria classe combatente e oprimida. Em Marx, ela aparece como a última classe escravizada, como a classe vingadora que consuma a tarefa de libertação em nome das gerações de derrotados ${ }^{24}$.

\footnotetext{
${ }^{23}$ BENJAMIN, "Sobre o Conceito de História". Opus. Cit. p. 228.

${ }^{24}$ Idem. p. 229.
} 
Com a falência da categoria do sujeito lógico-transcendental o espaço de indefinição que caracteriza a existência do homem moderno pode ser preenchido de diferentes maneiras possíveis. Na óptica de Benjamin predomina a ciência e o cientificismo (adesão sem crítica às suas práticas), redimensionando a razão em sentido tecnológico, abandonando o ideal de contemplação e de reflexão, ao mesmo tempo em que o mercado se impõe como sucedâneo pela busca da felicidade. Surge o mundo do espetáculo e do fetichismo. Dá-se a despolitização da política. A existência passa a ser totalmente administrada, regida pela violência institucionalizada pelo Estado. Até a "honra" é objeto a ser manipulado, controlado como foi a honra do povo judeu:

A honra pode ser afetada tanto pela conduta vergonhosa de um parente
como pela ofensa que atinge nosso próprio corpo. E o nome, que com sua
própria inviolabilidade quer representar a inviolabilidade aparentemente
abstrata da pessoa, não é, no contexto da vida da criatura (embora não no
contexto da religião), nada em si mesmo a não ser o escudo destinado a
recobrir a physis vulnerável do ser humano. O homem desonrado é um
proscrito $^{25}$.

A modernidade traz a falência da compreensão humanitária de cidadania e de democracia, inseparáveis da vida ética, tão sonhada pelos alemães, na República de Weimar. Com o Nazismo no poder, os alemães perderam o domínio do controle de suas próprias vidas. O ideário nazista confiscou a dimensão do futuro pela confusão entre o possível e o "necessário", em que o futuro só é convocado para justificar a barbárie que se faz no presente, pois, para os alemães, o império (der dritte Reich) permaneceria por 1000 anos. Ironicamente sua temporalidade foi o efêmero, o descartável, que dissolveu a dimensão ética das relações - um universo governado pelo absurdo, onde os direitos humanos se viram execrados:

Se o início da guerra se dará no contexto das normas do direito internacional, depois de uma declaração de guerra, é discutível; em todo caso, seu fim não estará condicionado a limitações desse gênero ${ }^{26}$.

Benjamin entende que a modernidade estabeleceu um conflito entre a ciência, a política e a moral, em que a ciência não se guia mais pela ideia de fim último, como no pensamento dos antigos, com a categoria do Sumo Bem, e por isso pode servir a qualquer fim, inclusive à guerra. Quanto mais se acumulam métodos e

\footnotetext{
${ }^{25}$ BENJAMIN, Origem do Drama Barroco Alemão. Opus. Cit. p. 109-110

${ }^{26}$ BENJAMIN, "Teorias do facismo alemão". Opus. Cit. p. 63.
} 
instrumentos, menor é seu sentido, o que a modernidade possui são destros escultores, incapazes de sequer questionarem se o Belo possui uma verdade ou o Bem como no pensamento platônico. Esse belo, na obra de arte, segundo Benjamin, possui "em seu interior algo que precisa ser conhecido". Na contemporaneidade o homem não faz "sua própria história" mas pretende reconstruir a própria natureza, desconhecendo qualquer limite moral. O capitalismo criou na sociedade alemã um clima de desconfiança e conformismo, que elimina qualquer esperança redentora, ou seja, qualquer possibilidade de vinda do "Messias", metáfora de iniciativa salvadora, pela interferência da ação consciente, da ação política.

\begin{abstract}
Em cada época, é preciso arrancar a tradição ao conformismo, que quer apoderar-se dela. Pois o Messias não vem apenas como salvador; ele vem também como vencedor do Anticristo. O dom de despertar no passado as centelhas da esperança é privilégio exclusivo do historiador convencido de que também os mortos não estarão em segurança se o inimigo vencer. $\mathrm{E}$ esse inimigo não tem cessado de vencer ${ }^{27}$.
\end{abstract}

Benjamin compreende que é preciso estabelecer a relação entre moral e política. Pois, "mobilizar as energias da embriaguez para a revolução" significa, inequivocamente, isolar a arte contra o otimismo que impregna o ar político dos "partidos da burguesia", cujo programa não passa de uma "péssima poesia de primavera, saturada de metáforas". Benjamin, entende que "o homem está sob o signo da transitoriedade", na busca por um sentido para a vida, e desde seus primeiros ensaios, deixa clara sua aversão à sociedade burguesa, em particular à burguesia alemã, onde o otimismo da social-democracia é como uma imagem do futuro perfeito, produzida pela visão de mundo sustentada pela fé cega no progresso da força do capital. Benjamin, com o mesmo tom premonitório, no ensaio "Teorias do facismo alemão", adverte contra uma continuação da Primeira Guerra Mundial, porém, com efeitos ainda mais devastadores. Logo, sua melancolia era uma reação ou uma resistência ao discurso político e ao rumo que as coisas tomavam na Europa das primeiras décadas do século XX e, particularmente, da República de Weimar. Ao pessimismo de Benjamin, era preciso acrescentar um elemento organizativo, criador de energias revolucionárias. Era preciso extrair "a metáfora moral da política", pois, na relação moral e política, é preciso distinguir a ação política da ação moral, os pressupostos teóricos e práticos da revolução:

\footnotetext{
${ }^{27}$ BENJAMIN, "Sobre o conceito de história". Opus. Cit. p.224.
} 
Organizar o pessimismo significa simplesmente extrair a metáfora moral da esfera da política, e descobrir no espaço da ação política o espaço completo da imagem. Mas esse espaço da imagem não pode de modo algum ser medido de forma contemplativa ${ }^{28}$.

A tarefa do intelectual revolucionário seria teórico-prática, a questão é se uma e outra devem ou não serem cumpridas simultaneamente. Quando Benjamin sugere a extração da metáfora moral da política indica que a revolução não se dá no campo das opiniões, à revelia de sua relevância. È com esse pensamento sobre a atividade intelectual e sobre a decadência da experiência (Erfahrung), que Benjamin converge sua compreensão de mundo para a relação entre estética e política na modernidade, buscando entender como as modernas relações de produção intelectual se originam no final do século XIX e se reconfiguram num contexto específico do século XX: os anos do fascismo e da guerra, o fim da República de Weimar e a ascensão do nazismo na Alemanha, com o apogeu do poder de Hitler e de sua transformação em Mito.

A inteligência que fala em nome do facismo deve desaparecer. A inteligência que o enfrenta, confiante em suas próprias forças miraculosas, há de desaparecer. Porque a luta revolucionária não se trava entre o capitalismo e a inteligência, mas entre o capitalismo e o proletariado ${ }^{29}$.

A técnica como conceito dialético aparece em Benjamin sob várias facetas e oferece ao intelectual melhores chances de combate político, além de perceber com maior nitidez os limites impostos ao intelectual e a própria reconfiguração da atividade intelectual, provocando rupturas com conceitos tradicionais, concernentes ao produtor e ao que é produzido. No texto Que é teatro épico?, Benjamin afirma que a distinção entre teatro épico e teatro tradicional é o conjunto de relações funcionais entre palco e público, texto e representação, diretor e atores, cujo objetivo é alterar funcionalmente tais relações e o conceito central é a refuncionalização (Umfunktionierung):

Mas, qualquer que tenha sido o funcionamento desse teatro político, do ponto de vista social ele se limitou a franquear ao público proletário posições que o aparelho teatral havia criado para o público burguês. As relações funcionais entre palco e público, texto e representação, diretor e

\footnotetext{
${ }^{28}$ BENJAMIN, "O surrealismo: o útimo instantâneo da inteligência européia". Opus. Cit. p. 34.

${ }^{29}$ BENJAMIN, "O autor como produtor". Opus. Cit. p. 136.
} 
atores quase não se modificam. O teatro épico parte da tentativa de alterar fundamentalmente essas relações ${ }^{30}$.

O teatro épico, como diz Benjamin, é destinado aos indivíduos que "não pensam sem motivo", ou seja, seu interesse é a transformação das massas em especialistas, mas isso só é possivel graças ao caráter (dialeticamente) alienante da interrupção da ação. Sem tal distanciamento, não há a descoberta das situações, mas apenas a sua reprodução. Para Benjamin, distanciar-se de uma situação vivida não significa, contudo, afastar-se da realidade. O caráter didático mediado pelo teatro épico, consiste em transformar o teatro num meeting político, em que a qualidade pensada por Benjamin no contexto da luta política depende das inovações técnicas:

O teatro épico se dirige a indivíduos interessados, que "não pensam sem
motivo". Mas essa é uma atitude que eles partilham com as massas. No
esforço de interessar essas massas pelo teatro, como especialistas, e não
através da "cultura", o materialismo histórico de Brecht se afirma
inequivocamente. "Desse modo, teríamos muito breve um teatro cheio de
especialistas, da mesma forma que um estádio esportivo está cheio de
especialistas"31.

No texto $O$ autor como reprodutor, Benjamin defende a tese de que buscar inovações técnicas significa libertar-se de correntes impostas pelo aparelho de produção do Estado burguês. Logo, o teatro épico representa para Benjamin, um exemplo de "alimentar um aparelho de produção e modificá-lo no sentido socialista" porque seu germe revolucionário está contido nas inovações técnicas que alteram completamente a função do teatro. Segundo Benjamin, foi isso que faltou ao surrealismo: uma arte capaz de mobilizar energias revolucionárias ${ }^{32}$. No caso de Brecht, mobilizar as massas operárias em torno de um teatro político:

[Brecht] criou o conceito de "refuncionalização" para caracterizar a transformação de formas e instrumentos de produção por uma inteligência progressista e, portanto, interessada na liberação dos meios de produção, a serviço da luta de classes. [...] O que se propõe são inovac̃ões técnicas, e não uma renovação espiritual, como proclamam os facistas ${ }^{33}$.

Segundo Benjamin, os interesses de classe se confudem com opções estético-políticas, que, por sua vez, remontam a problemas sem soluções, como a

\footnotetext{
${ }^{30}$ BENJAMIN, W. "Que é teatro épico". Sobre a coletânea Guerras e Guerreiros, Editada por Ernest Junger. In: _Magia e técnica, Arte e política, Ensaio Sobre Literatura e História da Cultura. Tradução de Sérgio Paulo Rouanet, $7^{a}$ ed. São Paulo: Brasiliense. 1994, p. 79.

${ }^{31}$ BENJAMIN, W. "Que é teatro épico Opus. Cit. p. 81.

${ }^{32}$ BENJAMIN, "O surrealismo: o útimo instantâneo da inteligência europeia". Opus. Cit. p. 32.

${ }^{33}$ BENJAMIN, "O autor como produtor". Opus. Cit. p. 127.
} 
relação entre forma e conteúdo. Logo, se a fusão das formas literárias é um mérito da técnica, esta última como conceito dialético também sofre constantes alterações, não apenas em função do desenvolvimento das forças produtivas, mas principalmente na função que desempenha no corpo social. E é nessa função que aparece a atuação crítica do intelectual pois, segundo Benjamin, cabe ao intelectual, perceber as rachaduras da armadura que protege o aparelho produtivo, por meio de uma atuação ambígua, capaz de dar conta da aplicação também ambígua da técnica, que pode tanto dissolver como reabilitar a crítica a essa fusão:

Somente a literalização de todas as relações vitais permite dar uma idéia exata do alcance desse processo de fusão, do mesmo modo que é o nível da luta de classes que determina a temperatura na qual se dá a fusão, de modo mais ou menos completo ${ }^{34}$.

Benjamin, em sua crítica ao progresso, aponta a rememoração enquanto gesto que destrói e rompe com as fantasmagorias capitalistas ${ }^{35}$, "esbofeteando" a sociedade a fim de despertá-la. Este gesto ético da memória, é o único que se pode realizar. Torna-se legítimo então, tentar entender como opera o "despertar" e de que forma poderá ou tentará o "anjo alegórico" salvar a humanidade da catástrofe em permanência na história e preparar uma outra percepção humana:

O anjo da história deve ter esse aspecto. Seu rosto está dirigido para o passado. Onde nós vemos uma cadeia de acontecimentos, ele vê uma catástrofe única, que acumula incansavelmente ruína sobre ruína e as dispersa a nossos pés. Ele gostaria de deter-se para acordar os mortos e juntar os fragmentos. Mas uma tempestade sopra do paraiso e prende-se em suas asas com tanta força que ele não pode mais fechá-las. Essa tempestade o impele irresistivelmente para o futuro, ao qual ele vira as costas, enquanto o amontoado de ruínas cresce até o céu. Essa tempestade é o que chamamos progresso ${ }^{36}$.

Benjamin se defrontou, nesse momento de expansão capitalista, em particular dos meios técnicos e seus reflexos na vida das pessoas, com uma Alemanha cheia de problemas, cuja unificação fora feita de "cima" para "baixo", com uma tradição antidemocrática, e, na medida em que se industrializara, vira as costas para lutas operárias, que a repressão policial já não controlava. Esses movimentos conduziram

\footnotetext{
${ }^{34}$ Idem. p. 130.

${ }^{35}$ Benjamin, ao fazer uma analise do Sistema Capitalista de Produção e do Materialismo histórico Marxista, observa que a superestrutura da sociedade capitalista sofre modificações de forma mais lenta que a base econômica, portanto, quaisquer mudança nas condições de produção precisam de tempo para se refletirem em todos os setores da cultura. Isto implica que os prognósticos marxistas, embora não possam ser subestimados, nem de longe, devem ser tomados como teses.

${ }^{36}$ BENJAMIN, "Sobre o conceito de história". Opus cit. p.226.
} 
os dirigentes e ativistas do movimento socialista à assimilação das ideias de Karl Marx. Segundo Benjamin, eles se apoiram excessivamente na dinâmica econômica, deixando a dimensão dialética marxista se apagar. Porém, essa dialética era decisiva na intervenção dos sujeitos da história no processo de transformação das condições existentes. Bismarck já havia preparado a Alemanha para o sucesso das forças produtivas com a criação de escolas e centros de capacitação técnica:

\begin{abstract}
A crescente proletarização dos homens contemporâneos e a crescente massificação são dois lados do mesmo processo. O fascismo tenta organizar as massas proletárias recém-surgidas sem alterar as relações de produção e propriedade que tais massas tendem a abolir. Ele vê sua salvação no fato de permitir às massas a expressão de sua natureza, mas certamente não a dos seus direitos ${ }^{37}$.
\end{abstract}

Diante das formulações teóricas de destaque, cujos conceitos estavam em consonância com a atmosfera da República de Weimar sobre a relação arte e sociedade, a reflexão benjaminiana vai gravitar em torno da análise do capitalismo. Dá ênfase a leitura de Karl Marx, na qual faz uma crítica ao sistema marxista, por este andar na esteira do ilumunismo e acreditar na "revolução como locomotiva da história". Marx detectou a luta de classes entre a burguesia e o proletariado como a contradição principal dessa sociedade. Porém, Marx não imaginava a prosperidade financeira e social que o sistema capitalista alcançaria, levando ao ajuntamento das massas e criando uma invejável produção de riquezas. Por outro lado, o capitalismo acarretou mudanças significativas na produção da arte e em sua percepção, na política e na cultura em geral, exigindo uma análise mais profunda e minuciosa das relações sociais e do binômio história-natureza. Benjamin chama à atenção para a fantasmagoria causada pelo progresso:

\begin{abstract}
Pensemos nos esplêndidos quadros de Ensor, nos quais uma grande fantasmagoria enche as ruas das metrópoles: pequeno-burgueses com fantasias carnavalescas, máscaras disformes brancas de farinha, coroas de folha de estanho, rodopiam imprevisivelmente ao longo das ruas. Esses quadros são talvez a cópia da renascença terrível e caótica, na qual tantos depositam suas esperanças ${ }^{38}$.
\end{abstract}

O materialismo histórico que Benjamin assimilou combinou com seu pensamento prévio de que era preciso alimentar a esperança de construir um mundo bem melhor, pois já tinha razões para isso, uma vez que constatou a existência de seres humanos explorados e oprimidos, cujo sofrimento matara até mesmo a

\footnotetext{
${ }^{37}$ BENJAMIN, "A obra de arte na era de sua reprodutibilidade técnica". Opus. Cit. p. 194.

${ }^{38}$ BENJAMIN, "Experiência e Pobreza”. Opus. Cit. p. 115.
} 
capacidade de sonhar um futuro animador. No ensaio sobre as Afinidades Eletivas (de Goethe) Benjamin expressa essa convicção com a frase: "A esperança só nos é dada em consideração àqueles que não tem mais esperança. Comenta ele que:

\begin{abstract}
O homem está no centro de suas experiências. O homem contemporâneo: reduzido, conservado em gelo num ambiente glacial. Porém como é o único a nossa disposição, temos interesse em conhecê-lo. Ele é sujeito a provas e a exames periciais. O resultado é o seguinte: o acontecimento não é transformável em seus momentos altos, pela virtude e pela decisão, mas unicamente em seu fluxo rigorosamente habitual, pela razão e pela prática $^{39}$.
\end{abstract}

Benjamin, diante desse novo paradigma para a humanidade, sente-se desafiado a desenvolver novos conceitos para explicar as relações, tendo em vista a transição da cultura clássica e do humanismo antropocêntrico do Renascimento para o capitalismo. No ensaio "A obra de arte na era de sua reprodutibilidade técnica" desenvolve o conceito de aura, que explica a relação entre a obra e seu admirador e que vai levá-lo à conclusão de que, quanto mais próximo da esfera sagrada, mais aurática é uma obra e mais valor de culto possui, e, quanto mais perde seu valor de culto, mais aumenta seu valor de exibição e sua possibilidade de democratizar-se. Surge o mercado como elemento regulador da autonomia estética, onde, por um lado, o artista tem que vender seu trabalho para sobreviver, por outro a obra para sobreviver tem que ter aceitação pública, como qualquer outro produto. Essa relação mercantil vai se estender a todas as dimensões da vida, criando uma nova percepção de mundo para o homem moderno:

\begin{abstract}
Em vez de perguntar: como se vincula uma obra com as relações de produção da época? É compatível com elas, e portanto reacionária, ou visa sua transformação, e portanto é revolucionária? - em vez dessa pergunta, ou pelo menos antes dela, gostaria de sugerir-vos outra. [...] Como ela se situa dentro dessas relações? Essa pergunta visa imediatamente à função exercida pela obra no interior das relações literárias de produção de uma época. Em outras palavras, ela visa de modo imediato à técnica literária das obras $^{40}$.
\end{abstract}

$\mathrm{Na}$ tentativa de libertação do Mito, o enigmático pensador do século $\mathrm{XX}$, Walter Benjamin, experimentou uma vida marcada por fracassos de ordem econômica, conjugal e acadêmica; acompanhou a ascensão da República de Weimar e o seu declínio, cuja bandeira foi substituída pela suástica do nacionalsocialismo. Benjamin foi perseguido pelo regime nazista na Alemanha na década de

\footnotetext{
${ }^{39}$ BENJAMIN, "O Autor Como Produtor". Opus. Cit. p. 134.

${ }^{40}$ BENJAMIN, "O Autor Como Reprodutor". Opus. Cit. p. 122
} 
30, sendo obrigado a fugir do país, passando a viver do pouco dinheiro que conseguia de suas publicações, especialmente junto à Revista do Instituto de Pesquisa Social de Frankfurt (Zeitschrift für Sozialforschung). Nesse período, escreveu várias cartas onde via a si próprio como o escritor da era moderna "pósaurática". Para Benjamin, a visão de um mundo que destruía a si próprio era insuportável. O mundo estava marcado pela degeneração causada por uma noção de "progresso linear", em que o Mito se instala na política, transformando-a em ideologia e dogmatismo:

$\mathrm{O}$ assombro com o fato de que os episódios que vivemos no século $X X$ "ainda" sejam possíveis, não é um assombro filosófico. Ele não gera nenhum conhecimento, a não ser o conhecimento de que a concepção de história da qual emana semelhante assombro é insustentável ${ }^{41}$.

Segundo Benjamin, compreender essa modernidade instaurada pelo capitalismo, implica em reconhecer também as mutações ocorridas no campo da cultura e das formas de expressão artística, dizendo a primeira destas mudanças com respeito ao desaparecimento da figura do "narrador". Benjamin parte da ideia de que a arte de contar histórias encontra-se em vias de extinção, porque ela se baseia na transmissão de uma experiência coletiva, cujas condições de realização não têm como sobreviver à sociedade capitalista. Em oposição à rapidez do processo de trabalho industrial, a narrativa reune a sabedoria de gerações, é feita de "memória: a mais épica das faculdades ${ }^{42}$.

A narrativa, que durante tanto tempo floresceu num meio de artesão - no
campo, no mar e na cidade -, é ela própria, num certo sentido, uma forma
artesanal de comunicação. Ela não está interessada em transmitir o "puro
em si" da coisa narrada como uma informação ou um relatório. Ela
mergulha a coisa na vida do narrador para em seguida retirá-la dele. Assim
se imprime na narrativa a marca do narrador, como a mão do oleiro na
argila do vaso ${ }^{43}$.

A nova forma de ficção, que traz o esgotamento da memória e da tradição, Benjamin analisa como forma característica da sociedade burguesa moderna, que leva o indivíduo a tornar-se isolado e desorientado, conseguindo encontrar-se apenas na solidão da forma romanesca. Tal isolamento se apresenta em todos os níveis, tanto na solidão do autor, do personagem, da história, como no nível do leitor. A modernidade, segundo Benjamin, foi responsável também por rasgar os véus das

\footnotetext{
${ }^{41}$ BENJAMIN, "Sobre o conceito de história". Opus. Cit. p. 226.

${ }^{42}$ BENJAMIN, "O Narrador". Opus. Cit. p. 210.

${ }^{43}$ Idem. p. 205.
} 
ilusões religiosas, uma vez que a arte apareceu originalmente relacionada aos rituais mágicos e à religião, tornando-se assim, ela própria, objeto de culto. Este fundamento religioso constituía a "autenticidade" da obra de arte, seu valor único que a distanciava de quem a admirava, o que Benjamin denomina de "aura". Foi graças ao surgimento de novas experiências de percepção artística e das circunstâncias ligadas à crescente difusão e intensidade dos fenômenos de massa que a arte perdeu rapidamente seu caráter sagrado e único. Com a destruição da aura, a arte pôde ser apropriada pelas massas, abrindo-se um espaço primeiro para aprendizado e simultaneamente para a prática democrática. Trata-se de uma saída para a sobrevivência da arte que leva em consideração sua nova situação de ente profanado e transformado em mercadoria. As novas expressões artísticas não auráticas tem de acompanhar o ritmo da técnica, a exemplo do rádio e do cinema, que são formas mais adaptadas para descrever as principais mudanças e o caráter fragmentário do mundo, expressos nas diversas linguagens da modernidade:

\begin{abstract}
Mesmo que essas novas circunstâncias deixem intacto o conteúdo da obra de arte, elas desvalorizam, de qualquer modo, o seu aqui e agora. [...] A autenticidade de uma coisa é a quintessência de tudo o que foi transmitido pela tradição, a partir de sua origem, desde sua duração material até o seu testemunho histórico. Como este depende da materialidade da obra, quando ela se esquiva do homem através da reprodução, também o testemunho se perde ${ }^{44}$.
\end{abstract}

Benjamin entende que não só a obra de arte foi profanada com a modernidade, mas o próprio autor, uma vez que ele ficou a mercê das leis do mercado, às leis da oferta e da procura. Por isso, Benjamin defende a tomada de consciência do autor como produtor, para a situação em que se encontra - a serviço de certos interesses de classes -, devendo reconhecer isso e tomar partido ao lado das classes revolucionárias. O autor deve romper com o simples modismo, que transforma a luta contra a miséria humana em artigo de consumo, sem quebrar a barreira entre autor e público. Nesse sentido, a expressão artística paradigmática para Benjamin, é o teatro épico de Brecht, que não se limita a abastecer o aparelho produtivo sem modificá-lo mas sim, realiza uma crítica desse próprio aparelho, tornando-o um exemplo de como o autor pode ser importante na construção de uma outra temporalidade que não a da exploração capitalista. Logo, o teatro épico para

\footnotetext{
${ }^{44}$ BENJAMIN, "A obra de arte na era de sua reprodutibilidade técnica". Opus. Cit. p. 168.
} 
Benjamin, é uma amostra de como a arte sem a aura pode utilizar as técnicas de reprodução para criar novas expressões, numa perspectiva de democratização:

\begin{abstract}
O teatro épico questiona o caráter de diversão atribuído ao teatro. Abala sua validade social ao privá-lo de sua função na ordem capitalista. E ameaça a crítica em seus privilégios. Estes residem num saber especializado, que habilita o crítico a fazer certos comentários sobre a direção e a interpretação ${ }^{45}$.
\end{abstract}

Benjamin lança sobre o mundo moderno um olhar barroco, que permite entender um mundo fragmentado, sem sentido, que se apresenta como um tempo de ruínas ${ }^{46}$, marcado pela busca do novo e pela efemeridade, um mundo construído de "cacos" que precisam ser avaliados. Deve-se interromper a história entendida como um desenrolar tranquilo do progresso da humanidade, pois esta é produto das classes dominantes e da paralisia espiritual dos historiadores. Benjamin entende a história como "objeto resultante de uma construção cujo lugar não é o tempo homogêneo e vazio, mas sim, um tempo saturado de 'agoras', um salto de tigre em direção ao passado"47 e, como concebeu Karl Marx, no materialismo histórico, esse mesmo salto, sob o livre céu da história, é o salto dialético da revolução, que embora se dê numa arena comandada por uma classe dominante, constitui o momento da ação consciente de fazer explodir o continuum da história, que é próprio às classes revolucionárias. Benjamin critica a eternização do passado pelo histocismo, bem como sua transformação pelo materialismo histórico, em uma experiência única:

O materialismo histórico não pode renunciar ao conceito de um presente que não é transição, mas pára no tempo e se imobiliza. Porque esse conceito define exatamente aquele presente em que ele mesmo escreve a história. O historicista apresenta a imagem "eterna" do passado, o materialista histórico faz desse passado uma experiência única ${ }^{48}$.

Benjamin não vê uma teleologia na história, ele acredita que a revolução seria uma parada para observar em que direção viaja o gênero humano. Rejeita o culto moderno do progresso e coloca a necessidade de resgatar o passado através de um presente redentor, no centro de sua visão de história, por entender que o passado

\footnotetext{
${ }^{45}$ BENJAMIN, "Que é teatro épico". Opus. Cit. p 86.

${ }^{46}$ Cf. CALLADO, T. "A experiência da origem". Opus. Cit. P. 78. Ruína para Benjamin é a metáfora para a multidão de deserdados pelo pensamento iluminista na sua sanha pela padronização; é a corvéia anônima cujos valores: coragem, confiança, firmeza e humor são atribuídos aos vencidos. Ruína é a massa de proscritos. Ruína é o amontoado de valores falsificados, paradigmas, normas e códigos vazios.

${ }^{47}$ BENJAMIN, "Sobre o conceito de história". Opus. Cit. p. 230.

${ }^{48}$ BENJAMIN, "Sobre o conceito de história". Opus. Cit. p. 230-231.
} 
nada mais é, do ponto de vista dos oprimidos, que uma série interminável de derrotas catastróficas. Segundo Benjamin, o progresso distancia o homem do paraíso e conduz ao seu oposto, ou seja, ao "inferno". Para ele a essência do "tempo infernal" (tempo moderno) é a eterna repetição do mesmo, do vício, da política que não deixa brecha para outras possibilidades, pois, na modernidade a atividade do trabalhador assalariado é o eterno recomeço a partir do zero, tendo de viver um tempo infernal baseado nos gestos automáticos repetindo a maquinaria das fábricas. Porém, não se trata somente do operário: o conjunto da sociedade moderna, dominada pela mercadoria, está submetida à repetição, ao sempre igual, disfarçado em novidade e moda - sob a aura do progresso. É diante de um quadro de Klee, chamado de Angelus Novus, que Benjamin define esse progresso:

\begin{abstract}
Angelus novus representa um anjo que parece querer afastar-se de algo que ele encara fixamente. Seus olhos estão escancarados, sua boca dilatada, suas asas abertas. [...] Mas uma tempestade sopra do paraíso e prende-se em uma de suas asas com tanta força que ele não pode mais fechá-las. Essa tempestade o impele irresistivelmente para o futuro, ao qual ele vira as costas, enquanto o amontoado de ruínas cresce até o céu. Essa tempestade é o que chamamos de progresso ${ }^{49}$.
\end{abstract}

Como diz Olgária Matos "revolução é atualização da tradição", em que essa estampa revolucionária se dá na ruptura do tempo homogêneo e vazio da história oficial. A perspectiva benjaminiana de democratização do mundo expressa a ideia de que, no tempo capitalista, a felicidade provisória dos vencedores continuará alicerçada sobre os corpos dos oprimidos, esquecidos e submersos nos porões da história. Somente a experiência de uma outra temporalidade - o "agora" -, resultante da luta pela salvação de um passado oprimido, poderá Intensificar a memória dos derrotados do passado, o que significa libertar a felicidade experienciada em oposição ao infinito tempo da necessidade e da catástrofe:

\footnotetext{
"Comparados com a história da vida orgânica na terra", diz um biólogo contemporâneo, "os míseros 50.000 anos do Homo sapiens representam algo como dois segundos ao fim de um dia de 24 horas. Por essa escala, toda a história da humanidade civilizada preencheria um quinto do último segundo da última hora". O "agora", que como modelo do messiânico abrevia num resumo incomensurável a história de toda a humanidade, coincide rigorosamente com o lugar ocupado no universo pela história humana $^{50}$.
}

\footnotetext{
${ }^{49}$ BENJAMIN, "Sobre o conceito de história". Opus. Cit. p. 226.

${ }^{50}$ BENJAMIN, "Sobre o Conceito de História". Opus. Cit. p. 231-232.
} 


\section{REFERÊNCIAS}

BENJAMIN, Walter. Documentos de Cultura, Documentos de Barbárie. São Paulo: Cultrix, Editora da Universidade de São Paulo, 1986.

. Obras escolhidas; Vol.I Magia e Técnica, Arte e política: ensaios sobre literatura e história da cultura. Tradução Sérgio Paulo Rouanet. 1. Ed. São Paulo: Brasiliense, 1985.

. Obras escolhidas; Vol.II - Rua de Mão Única. Tradução de Rubens Rodrigues Torres Filho e José Carlos Martins Barbosa. 5. Ed. São Paulo: Brasiliense, 1995.

. Obras escolhidas; Vol.III - Charles Baudelaire, um Lírico no Auge do Capitalismo. Tradução de José Carlos Martins Barbosa e Hemerson Alves Baptista. 3. Ed. São Paulo: Brasiliense, 1989.

O Conceito de crítica de arte no romantismo alemão. Tradução, prefácio e notas de Márcio Seligmann Silva. São Paulo: lluminuras,1993.

. Origem do Drama Barroco Alemão. Tradução de Sergio Paulo Rouanet. São Paulo: Brasiliense, 1984.

. Passagens. São Paulo: Editora UFMG, 2009.

CALLADO, Tereza de Castro. Walter Benjamin e a Experiência da Origem. Fortaleza: EdUECE, 2006.

Fortaleza: EdUECE, 2004.

"O drama da alegoria no século XVII barroco" in:_Kalagagos.

. "O comportamento ex-officio do Estadista na Teoria da soberania em Origem do Drama Barroco Alemão" in:_Coletânea Ética e Metafísica, Coleção Argetum Nostrum. Fortaleza: EdUECE, 2007.

REICH, Wilhelm. Psicologia de Massas do Facismo. Tradução de Maria da Graça M. Machado. São Paulo: Martins Fontes, 2001. 